\title{
Thyroid Function in Kuwaiti Subjects with Down's Syndrome
}

\author{
Fawzi E. Alia Hossam A. Bayoumy ${ }^{b}$ Abdul Salam R. Mohammada \\ Waleed A. Al-Busairia Abdul Naser A. Al-Othman' ${ }^{b}$ \\ aMedical Rehabilitation Centre, Ministry of Social Affairs and ${ }^{b}$ Endocrinology Unit, Department of Medicine, \\ Al-Sabah Hospital, Kuwait, Kuwait
}

\section{Key Words}

Down's syndrome $\cdot$ Hyperthyroidism $\cdot$ Hypothyroidism . Thyroid antibodies . Thyroid function tests

\begin{abstract}
Objective: To investigate the thyroid function of individuals with Down's syndrome (DS). Methods: Thyroid function and antithyroid antibodies were measured in 58 Kuwaitis with DS who resided at a residential facility or attended rehabilitation centers. Results: Twenty-six subjects (45\%) were euthyroid and $32(55 \%)$ had thyroid dysfunction. One patient had previously been diagnosed with thyroid failure whereas the other 31 patients had newly discovered disease: 9 patients had primary hypothyroidism $\left(\mathrm{T}_{4} 9.95 \pm 1.1 \mathrm{pmol} / \mathrm{l}\right.$ and TSH $15.15 \pm$ $11.93 \mathrm{mU} / \mathrm{l}), 19$ subclinical hypothyroidism (TSH $6.47 \pm$ $2.57 \mathrm{mU} / \mathrm{l}), 1$ secondary hypothyroidism, 1 hyperthyroidism, and the remaining 1 subclinical hyperthyroidism. Antithyroid antibodies were found in $52 \%$ of the total subjects and in 59\% of those with thyroid dysfunction. Conclusions: Thyroid dysfunction is common in Kuwaiti subjects with DS and is presumably the consequence of autoimmune thyroid disease. Periodic thyroid function testing is recommended in individuals with DS, which is best done through a national program.
\end{abstract}

Copyright $\odot 2002$ S. Karger AG, Basel

\begin{tabular}{ll}
\hline KARGER & ( ) 2002 S. Karger AG, Basel \\
1011-7571/02/0114-0206\$18.50/0 \\
$\begin{array}{l}\text { Fax +4161306 1234 } \\
\begin{array}{l}\text { E-Mail karger@karger.ch } \\
\text { www.karger.com }\end{array}\end{array}$ & $\begin{array}{l}\text { Accessible online at: } \\
\text { www.karger.com/mpp }\end{array}$
\end{tabular}

\section{Introduction}

Many cross-sectional studies have documented a high prevalence of thyroid abnormalities in individuals with Down's syndrome (DS) (table 1) [1-18]. Such abnormalities include hypofunction, hyperfunction, positive antithyroid antibodies, goiter, abnormal thyroid gland histology, and abnormal thyroid tests, singly or in various combinations. The comparison between these studies is somewhat limited by differences in the selected population and the diagnostic criteria. The most common thyroid abnormality is subclinical hypothyroidism: high serum thyroidstimulating hormone (TSH) with normal free thyroxine $\left(\mathrm{T}_{4}\right)$. The incidence of hypothyroidism in DS is much more than that of hyperthyroidism. Individuals with DS have been shown to have higher mean basal TSH levels and lower mean thyroid hormone concentrations compared with controls $[2,15]$. Since the manifestations of hypothyroidism are nonspecific and may be masked by the features of DS, the diagnosis of hypothyroidism in DS largely depends on biochemical testing rather than the clinical features of the disease. These difficulties in ascertaining clinical symptoms - in addition to the generally observed decline in thyroid function with advancing age highlight the need for periodic thyroid function testing in this population $[6,14]$. These tests should include thyroid

\footnotetext{
Fawzi E. Ali

Medical Rehabilitation Centre, Ministry of Social Affairs

PO Box 1240

45713 Surra (Kuwait)

Tel. +965 6510531, Fax +965 4875409, E-Mail fawzi@kma.org.kw
} 
Table 1. Thyroid function studies in DS (in ascending chronological order)

\begin{tabular}{|c|c|c|c|c|c|c|c|}
\hline Country & Author & Subjects & Cases & $\begin{array}{l}\text { Age } \\
\text { years }\end{array}$ & $\begin{array}{l}\text { Control } \\
\text { group }\end{array}$ & $\begin{array}{l}\text { Total } \\
\text { with thyroid } \\
\text { dysfunction, } \%\end{array}$ & $\begin{array}{l}\text { Total } \\
\text { with thyroid } \\
\text { antibodies, } \%\end{array}$ \\
\hline Australia & Baxter et al. [1] & inpatient & 11 & $44-65$ & no & 63 & 45 \\
\hline UK & Murdoch et al. [2] & inpatient & 82 & $19-65$ & yes & 40 & 13.4 \\
\hline Denmark & Korsager et al. [3] & mixed & 24 & $41-60$ & yes & 33 & 33 \\
\hline USA & Sare et al. [4] & inpatient & 121 & $13-48$ & no & 20 & 33 \\
\hline UK & Lobo et al. [5] & outpatient & 101 & $5-47$ & no & 16 & 29 \\
\hline USA & Pueschel and Pezullo [6] & outpatient & 151 & $3-21$ & yes & 27 & 31 \\
\hline UK & Loudon et al. [7] & outpatient & 116 & $\begin{array}{l}9 / 12-19 \\
10 / 12\end{array}$ & no & 3.4 & 29 \\
\hline USA & Cutler et al. [8] & outpatient & 49 & $4 / 12-3$ & yes & 37 & 8 \\
\hline UK & Kinnell et al. [9] & inpatient & 111 & $22-72$ & yes & 19 & 29 \\
\hline UK & Mani [10] & inpatient & 55 & $24-67$ & no & 22 & 16 \\
\hline USA & Friedman et al. [11] & outpatient & 138 & $2-59$ & no & 21.7 & 39 \\
\hline USA & Zori et al. [12] & mixed & 61 & $5 / 12-48$ & no & 66 & 28 \\
\hline Italy & Pozzan et al. [13] & outpatient & 108 & $3 / 12-38$ & no & 37 & 12 \\
\hline UK & Dinani and Carpenter [14] & mixed & 106 & $20-67$ & no & 40.5 & 34 \\
\hline USA & Pueschel et al. [15] & outpatient & 181 & $1-29$ & yes & 16.5 & $?$ \\
\hline Australia & Selikowitz [16] & outpatient & 101 & $\begin{array}{l}2 / 52-11 \\
4 / 12\end{array}$ & no & 13 & 23 \\
\hline Italy & Rubello et al. [17] & outpatient & 344 & $1-53$ & yes & 34 & 18 \\
\hline Sweden & Ivarsson et al. [18] & outpatient & 70 & $1-19$ & yes & 25.7 & 39 \\
\hline
\end{tabular}

antibody testing since they are found in $8-45 \%$ of DS subjects (table 1). The general incidence of DS in Kuwait's mixed population is $1.5 / 1,000$ live births, but reaches $3.6 /$ 1,000 live births among the Kuwaiti population, which is characterized by a high fertility and consanguinity rate [19]. Most of the large studies of thyroid disorders in DS have originated from the developed Western countries. Except for an earlier case report [20], ours is the first study investigating thyroid function in Kuwaiti subjects with DS.

\section{Subjects and Methods}

\section{Subjects}

Fifty-eight Kuwaitis with DS who were served by facilities for the disabled were studied. Twenty-five subjects were residents of an institution for the mentally retarded. The remaining 33 lived in the community and attended rehabilitation centers. There were 40 males and 18 females, with a mean age of $24.29 \pm 8.82$ years (ranging from 11 to 42). Although the age range was large, almost two thirds of the subjects were young adults: 18 in the age-group of 11-19 years, 25 between 20 and 29 years, 12 between 30 and 39, and 3 age 40 or older. Consent was obtained from the next of kin of all subjects, and the study was approved by the Human Subjects Review Committee of the Medical Rehabilitation Center.
The clinical diagnosis of DS was confirmed by Giemsa banding of chromosomes from peripheral lymphocytes. Fifty-seven patients had the trisomy 21 pattern and 1 was mosaic (normal/trisomy 21). Ten subjects had moderate mental retardation, 30 had severe mental retardation, and 18 had profound mental retardation. None of the subjects had a concurrent illness during the time of the study; only 1 patient, who was diagnosed prior to the study with postradioactive iodine hypothyroidism, was receiving thyroxine replacement therapy.

\section{Laboratory Tests}

Serum free $\mathrm{T}_{4}$ was measured by the ELISA/competition kit (Enzymon-Test $\mathrm{FT}_{4}$, Boehringer Mannheim, Germany); reference range 11.8-24.6 pmol/1. Serum TSH was measured by the ELISA/one-step sandwich kit (Enzymon-Test TSH, Boehringer Mannheim); reference range $0.23-3.8 \mathrm{mU} / 1$, with a lower detection limit of $0.05 \mathrm{mU} / 1$. The intra-assay coefficient of variation was $2 \%$, and the interassay coefficient of variation was $2.5 \%$ for both tests. Antibodies to thyroglobulin and thyroid peroxidase enzyme ( $\mathrm{TgAb}$ and $\mathrm{TPOAb}$, respectively) were measured by quantitative enzyme immunoassay, using commercial kits (Varelisa, Elias, Germany). Values $\geq 60 \mathrm{IU} / \mathrm{ml}$ for males and $\geq 100 \mathrm{IU} / \mathrm{ml}$ for females were considered positive, for both antibodies.

\section{Statistical Analysis}

Data were expressed as mean \pm SD. Statistical analyses were done using Student's $t$ test and Mann-Whitney test. A $p$ value $<0.05$ was considered significant. 
Table 2. Results of thyroid function tests in 58 Kuwaitis with DS

\begin{tabular}{|c|c|c|c|c|c|c|c|c|c|}
\hline \multirow[t]{2}{*}{ Hormonal values } & \multicolumn{2}{|c|}{ Subjects } & \multirow[t]{2}{*}{$\begin{array}{l}\mathrm{T}_{4}, \mathrm{pmol} / 1 \\
(11.8-24.6)\end{array}$} & \multirow[t]{2}{*}{$\begin{array}{l}\mathrm{TSH}, \mathrm{mU} / 1 \\
(0.23-3.8)\end{array}$} & \multicolumn{2}{|c|}{$\begin{array}{l}\text { Positive } \\
\text { antibodies }\end{array}$} & \multirow[t]{2}{*}{$\begin{array}{l}\text { Only } \\
\text { TgAb }\end{array}$} & \multirow[t]{2}{*}{$\begin{array}{l}\text { Only } \\
\text { TPOAb }\end{array}$} & \multirow[t]{2}{*}{$\begin{array}{l}\text { TgAb and } \\
\text { TPOAb }\end{array}$} \\
\hline & $\mathrm{n}$ & $\%$ & & & $\mathrm{n}$ & $\%$ & & & \\
\hline Euthyroid & 26 & 45 & $15.08 \pm 1.42$ & $2.41 \pm 0.77$ & $10 / 25$ & 40 & 3 & 3 & 4 \\
\hline Primary hypothyroidism & 10 & 17 & $9.95 \pm 1.10$ & $15.15 \pm 11.93$ & 7 & 70 & 1 & 2 & 4 \\
\hline Subclinical hypothyroidism & 19 & 33 & $14.41 \pm 1.23$ & $6.47 \pm 2.57$ & $10 / 18$ & 56 & 2 & 4 & 4 \\
\hline Secondary hypothyroidism & 1 & 2 & 9.74 & 2.55 & & & & & \\
\hline Hyperthyroidism (only increased $\mathrm{T}_{4}$ ) & 1 & 2 & 25.77 & 0.55 & 1 & - & & & 1 \\
\hline Subclinical hyperthyroidism & 1 & 2 & 22.08 & 0.21 & 1 & - & 1 & & \\
\hline Total with thyroid dysfunction & $32 / 58$ & 55 & & & $29 / 56$ & 52 & 7 & 9 & 13 \\
\hline
\end{tabular}

\section{Results}

Twenty-six patients ( $45 \%)$ had both serum-free $\mathrm{T}_{4}$ and TSH levels within the normal range (table 2). The mean $\mathrm{T}_{4}$ for these patients was $15.08 \pm 1.42 \mathrm{pmol} / \mathrm{l}$ (range $12.40 \pm 18.89)$ and the mean TSH $2.41 \pm 0.77 \mathrm{mU} / 1$ (range $0.42-3.51$ ). The other 31 patients had abnormal $\mathrm{T}_{4}$ and/or TSH values. Of these, $9(16 \%)$ subjects had a mean $\mathrm{TSH}$ of $15.15 \pm 11.93 \mathrm{mU} / \mathrm{l}$ (range 4.27-39.30) and a mean $\mathrm{T}_{4}$ of $9.95 \pm 1.1 \mathrm{pmol} / \mathrm{l}$ (range 8.47-11.58), indicating primary hypothyroidism. Nineteen $(33 \%)$ subjects had a mean TSH $6.47 \pm 2.57 \mathrm{mU} / \mathrm{l}$ (range 3.82-13.73), indicating subclinical hypothyroidism. The remaining 3 subjects with thyroid dysfunction had each an individual pattern of decreased $T_{4}(9.74 \mathrm{pmol} / \mathrm{l})$, elevated $\mathrm{T}_{4}$ (25.77 pmol/1), or decreased TSH $(0.21 \mathrm{mU} / \mathrm{l})$. The first subject further had TRH stimulation test that was normal and an MRI of the hypothalamus-pituitary region, which showed normally enhanced sella turcica with central stalk. These findings are consistent with secondary hypothyroidism. The third subject who had bilateral exophthalmos also had TRH stimulation test, which showed a flat response, consistent with subclinical hyperthyroidism.

The $\mathrm{T}_{4}$ values for males and females were $14.64 \pm 3.07$ and $13.70 \pm 2.8 \mathrm{pmol} / \mathrm{l}$, respectively $(\mathrm{p}=0.668)$. The $\mathrm{TSH}$ values for males and females were $4.60 \pm 3.61$ and $8.01 \pm 10.27 \mathrm{mU} / \mathrm{l}$, respectively $(\mathrm{p}=0.217)$. There was no statistically significant difference by gender for $\mathrm{T}_{4}$ and $\mathrm{TSH}$. The $\mathrm{T}_{4}$ values for primary hypothyroidism and subclinical hypothyroidism were $9.95 \pm 1.0$ and $14.41 \pm$ $1.23 \mathrm{pmol} / 1$, respectively $(\mathrm{p}=0.384)$, indicating that there was no statistically significant difference between the two. The TSH values for primary and subclinical hypothyroidism were $15.15 \pm 11.9$ and $6.47 \pm 2.57 \mathrm{mU} / 1$, respective- ly $(p=0.015)$, indicating that there was a statistically significant difference between the two.

For antibody testing, 29 were positive, 27 were negative, and the test was not given to 2 patients ( 1 with normal thyroid function and the other with hyperthyrotropinemia). For the positive patients, 7 had only $\mathrm{TgAb}, 9 \mathrm{had}$ only TPOAb, and 13 had both. Nineteen (65\%) had thyroid dysfunction: 7 had primary hypothyroidism, 10 subclinical hypothyroidism, 1 elevated $\mathrm{T}_{4}$ and 1 reduced TSH. Thyroid dysfunction was found in $40 \%$ of the institutionalized subjects and $57 \%$ of the community-living subjects, similar to their corresponding composition (43 and $57 \%$ ) of the study group, thereby indicating there was no bias in the selection of the subjects.

\section{Discussion}

Our study reveals a high frequency of thyroid dysfunction $(55 \%)$ and of thyroid autoimmunity (52\%) in Kuwaitis with DS, many of whom suffer from either severe or profound mental retardation. These values are higher than those of most other reports, partly due to our liberal diagnostic criteria which included individuals with only mildly elevated TSH. However, when our results are compared to those of other studies using similar diagnostic criteria, the values $(55 \%)$ fall within the reported range (37-66\%) of thyroid dysfunction [12-14]. For thyroid antibodies, our value was also higher than those of previous reports (table 1), most probably due to the sensitivity of the test we used (ELISA), compared to those of others (coated red cell hemaglutination). However, the fact that our sample size was relatively small and that we did not have a control group might have affected our results. 
No sex difference was seen in $\mathrm{T}_{4}$ or TSH values, which is in agreement with most studies. Of two dissenting studies, one found more hypothyroidism in males [6] and the other found more hypothyroidism in females under 20 years of age [4]. The TSH level was significantly higher in the group with primary hypothyroidism compared to the group with subclinical hypothyroidism, but the difference in $\mathrm{T}_{4}$ levels between the two groups was not statistically significant. Our data confirm previous reports that hypothyroidism is much more common than hyperthyroidism in DS [1-18].

The findings of 55\% for thyroid dysfunction and 52\% for positive thyroid antibodies in this study indicate that the presence of thyroid antibodies constitutes a marker for thyroid dysfunction in people with DS [1-18]. Moreover, we found that the prevalence of positive antibodies increased with the extent of aberration of thyroid function tests: euthyroid $40 \%$, subclinical hypothyroidism $56 \%$, and primary hypothyroidism $70 \%$. Rubello et al. [17] found that subclinically hypothyroid subjects with positive antibodies were much more likely to develop overt hypothyroidism on follow-up than those with negative antibody results. The findings of this investigation $-55 \%$ aberrations of thyroid function tests with $52 \%$ positive antithyroid antibodies in Kuwaiti subjects with DS - indicate inadequate screening for thyroid disease. With periodic testing, individuals with significantly abnormal results can be identified early before clinical symptoms become manifest.

\section{Conclusion}

Thyroid dysfunction is common in Kuwaiti subjects with DS. This dysfunction resulting from thyroid autoimmune disease increases as the level of thyroid antibodies increases. We recommend routine thyroid function testing in DS subjects, in particular as they advance in age.

\section{References}

1 Baxter RG, Larkins RG, Martin FI, Heyma P, Myles K, Ryan L: Down syndrome and thyroid function in adults. Lancet 1975; ii:794-796.

2 Murdoch JC, Ratcliffe WA, McLarty DG, Rodger JC, Ratcliffe JG: Thyroid function in adults with Down syndrome. J Clin Endocrinol Metab 1977;44:453-458.

3 Korsager S, Chatham EM, Ostergaard Kristensen HP: Thyroid function tests in adults with Down syndrome. Acta Endocrinol 1978; 88:48-54.

4 Sare Z, Ruvalcaba RH, Kelley VC: Prevalence of thyroid disorder in Down syndrome. Clin Genet 1978;14:154-158.

5 Lobo EDH, Khan M, Tew J: Community study of hypothyroidism in Down syndrome. BMJ 1980;280:1253.

6 Pueschel SM, Pezzullo JC: Thyroid dysfunction in Down syndrome. Am J Dis Child 1985; 139:636-639.

7 Loudon MM, Day RE, Duke EM: Thyroid dysfunction in Down syndrome. Arch Dis Child 1985;60:1149-1151.

8 Cutler AT, Benezra-Obeiter R, Brink SJ: Thyroid function in young children with Down syndrome. Am J Dis Child 1986;140:479-783.
9 Kinnell HG, Gibbs N, Teale JD, Smith J: Thyroid dysfunction in institutionalised Down syndrome adults. Psychol Med 1987;17:387392.

10 Mani C: Hypothyroidism in Down syndrome. Br J Psychiatry 1988;153:102-104.

11 Friedman DL, Kastner T, Pond WS, O'Brien DR: Thyroid dysfunction in individuals with Down syndrome. Arch Intern Med 1989;149: 1990-1993.

12 Zori RT, Schatz DA, Ostrer H, Williams CA, Spillar R, Riley WJ: Relationship of autoimmunity to thyroid dysfunction in children and adults with Down syndrome. Am J Med Genet Suppl 1990;7:238-241.

13 Pozzan GB, Rigon F, Girelli ME, Rubello D, Busnardo B, Baccichetti C: Thyroid function in patients with Down syndrome: Preliminary results from non-institutionalized patients in the Veneto region. Am J Med Genet Suppl 1990;7: 57-58.

14 Dinani S, Carpenter S: Down syndrome and thyroid disorder. J Ment Defic Res 1990;34: 187-193.

15 Pueschel SM, Jackson IM, Giesswein P, Dean MK, Pezzullo JC: Thyroid function in Down syndrome. Res Dev Disabil 1991;12:287-296.
16 Selikowitz M: A five-year longitudinal study of thyroid function in children with Down syndrome. Dev Med Child Neurol 1993;35:396401.

17 Rubello D, Pozzan GB, Casara D, Girelli ME, Boccato S, Rigon F, Baccichetti C, Piccolo M, Betterle C, Busnardo B: Natural course of subclinical hypothyroidism in Down syndrome: Prospective study results and therapeutic considerations. J Endocrinol Invest 1995;18:3540.

18 Ivarsson SA, Ericson UB, Gustafsson J, Forslund M, Vegfors P, Anneren G: The impact of thyroid autoimmunity in children and adolescents with Down syndrome. Acta Paediatr 1997;86:1065-1067.

19 Farag TI, Al-Awadi SA, Al-Othman SA, Sundareshan TS, Krishna Murthy DS, Usha R, Mady SA, Uma R: Down syndrome and trisomy 18 in the Bedouins. Am J Med Genet 1988; 29:943-944.

20 Ali FE, Al-Busairi WA, Al-Mulla FA: Treatment of hyperthyroidism in Down syndrome: Case report and review of the literature. Res Dev Disabil 1999;20:297-303. 